\title{
Adequacy and Relevance of Medical Records of Patients Admitted Following Medico-Legally Significant Trauma
}

\author{
Priyanath $\mathrm{DC}^{1 *}$, Dharmadasa $\mathrm{LS}^{1}$, De Silva RLSK ${ }^{1}$, Gunathilaka MMACC ${ }^{1}$, Nanayakkara EHHG ${ }^{2}$, Shakoor $\mathrm{MS}^{2}$. \\ Samarawickrama $\mathrm{S}^{2}$, Kitulwatte $\mathrm{IGD}^{1}$, Edirisinghe PAS $^{1}$. \\ ${ }^{1}$ Department of Forensic Medicine, Faculty of Medicine, University of Kelaniya, Ragama, Sri Lanka. \\ ${ }^{2}$ Office of the Judicial Medical Officer, District General Hospital, Matara, Sri Lanka.
}

\begin{abstract}
Introduction: Details mentioned in Bed head ticket (BHT) and investigations are taken into consideration when an opinion is made with regards to the medico legally significant trauma. Shortfalls of documents can lead to misdiagnosis or wrongful diagnosis. This study was conducted to find out the adequacy of records on BHTs and availability of investigations on patients who had been admitted following trauma with medico legal significance.
\end{abstract}

Methods: A prospective descriptive study was carried out on patents who were admitted following medico-legally significant trauma during a period of one year, from Aug 2017 to Aug 2018 by perusing their records. The adequacy of the documentation was assessed according to a pre-prepared scale.

Results: Analysis of on admission historical and preliminary details revealed that out of 1102 records, only $26 \%$ $(\mathrm{n}=286)$ had mentioned the time duration since the incident. Recorded cardiovascular stability on admission was above $86 \%(n=950)$ though level of consciousness was not mentioned by $19 \%(n=211)$. Nature of the injuries were correctly recorded by $65 \%(n=720)$ while the location of them were correctly recorded only by $29 \%(n=316)$. Surgical procedures were adequately mentioned only among $39 \%(\mathrm{n}=425)$.

Conclusions: The study revealed that there are gross inadequacies with regard to the records on BHTs made by the doctors. This can lead to limitations in addressing medico-legal issues and sometimes can result in wrong opinions leading to injustice. Need for continuous professional training with special attention to record keeping is highlighted. Further, the quality of records can be further improved with regular audits, continuous professional developmental activities and introducing a common format for documentation in admission, surgical procedures and investigations.

Keywords: Medico-legal issues, medical record keeping, adequacy, investigations, BHT

Received: 02 Nov 2019, Revised version accepted: 26 Jan 2020, Published: 30 June 2020. *Corresponding author: Priyanath DC, \lemail: priyanathdc@gmail.com (DORCID: https://orcid.org/0000-0002-3136-3299

Cite this article as: Priyanath DC, Dharmadasa LS, De Silva RLSK, Gunathilaka MMACC, Nanayakkara EHHG, Shakoor MS. Samarawickrama S, Kitulwatte IGD, Edirisinghe PAS. Adequacy and Relevance of Medical Records of Patients Admitted Following Medico-Legally Significant Trauma. Medico-Legal Journal of Sri Lanka. 2020;8(1):1-7. DOI: http://doi.org/10.4038/mljsl.v8i1.7397

Copyright: @ 2019 with the Medico-legal Journal of Sri Lanka.

This is an open-access article distributed under the terms of the Creative Commons Attribution 4.0 International License, which permits unrestricted use, distribution and reproduction in any medium provided the original author and source are credited.

\section{Introduction}

Injuries and ailments of the forensic patients are needed to be reported to the legal authority. The severity of the hurt is categorized in the Penal Code of Sri Lanka and accordingly physicians working in the capacity of Medical Officer Medico Legal and the specialists in forensic medicine are expected to give a detailed report regarding the injuries and their category. ${ }^{[1,2]}$ Punishment is decided by Court of law according to the category of hurt. Clinicians are required, both medically and legally, to maintain an adequate record for each patient. Further, the physician is liable for the proper maintenance, custody, and storage of the records for the required statutory period. Although the structure and quality of medical records has been a matter of clinical, 
administrative and legal interest for many years the professionals have engaged in a dialog of developed standards in the first part of the millennium. ${ }^{[3,4]}$ Yet, poor record keeping and inadequacies in investigations are observed which in turn can lead to difficulties in giving a proper medico-legal opinion. Legible, complete notes on admission regarding the condition of the patient as well as the notes on surgical procedures are extremely important in formulation of a medico-legal opinion. Inadequacies of required investigations can lead to misdiagnosis or wrongful diagnosis. This may be due to unavailability of such investigations, cost as well as due to the risk in exposure and not compiling available data methodically. Further the knowledge and the attitudes of the medical officers sharing medical information among professionals as well as patients also contribute notoriously for this. ${ }^{[5]} \mathrm{On}$ the other hand, there are some circumstances when there is a medico-legal relevance; doctors claim to do more in the way of management than they believe to be necessary on medical grounds. This may put the patients to inconvenience and even risk. There can be numerous unnecessary radiological investigations because majority of investigations are for exclusion of injuries. Further, the economic burden especially as a middle income country is a fact where medico-legal doctors should be aware of it but it is a matter of debate sometimes when we consider the final outcome, justice. ${ }^{[6]}$ Documenting patient encounters is a challenge to the medical officers. Maintaining proper medical records ensures quality of care, continuity of care, assessment of care, and evidence of care. However, medical education disgracefully gives inadequate attention to teaching physicians how to properly document the patient encounter. This study was conducted to determine the adequacy and relevance of information recorded on the bed head ticket of patients with medico-legally significant trauma.

\section{Methodology}

This was a prospective descriptive study carried out in Colombo North Teaching Hospital Ragama and the District General Hospital Matara. Bed head tickets (BHT) of patients who were admitted following trauma and referred for medico-legal examination. Total sample was 1102. Data retrieved from BHTs was recorded in a proforma and entered in the SPSS statistical package. Adequacy or inadequacy of the records were assessed considering the standard practice and categorized according to a scale which consists of three sections; mentioned, partially mentioned or not mentioned. Frequencies and percentages of different recorded anonymous data were analyzed and the variation of the recorded notes according to the category of hurt was analyzed using SPSS 22 statistical soft wear. Ethical clearance was obtained from the Ethics Review board of Faculty of Medicine, University of Kelaniya.

\section{Results}

\section{Age distribution}

The documented age on BHTs of patients who were admitted following trauma, were analyzed according to the following age categories. The majority of patients were within the age of 25 to 40 years. About $61 \%(n=674)$ of patients were within the age of 25 to 60 years. Table 01 shows the distribution of the age.

Table 01: Age Distribution

\begin{tabular}{lr}
\hline Age (years) & $\begin{array}{r}\mathbf{N}=\mathbf{1 1 0 2} \\
\text { \% (n) }\end{array}$ \\
\hline $\mathbf{1 2}$ & $04(43)$ \\
$\mathbf{1 3 - 1 8}$ & $08(92)$ \\
$\mathbf{1 9 - 2 4}$ & $17(187)$ \\
$\mathbf{2 5 - 4 0}$ & $33(361)$ \\
$\mathbf{4 1 - 6 0}$ & $28(313)$ \\
$>\mathbf{6 1}$ & $10(106)$
\end{tabular}

The category of hurt of the majority $(64 \%, n=704)$ was non-grievous followed by grievous hurt (32\%, $\mathrm{n}=353$ ). Table 02 shows the distribution of the categories of hurt.

Table 02 : Categories of hurt distribution.

\begin{tabular}{lr}
\hline Category of hurt & $\begin{array}{r}\mathbf{N}=\mathbf{1 1 0 2} \\
\text { \% (n) }\end{array}$ \\
\hline Non grievous & $64(704)$ \\
Grievous & $32(353)$ \\
Endangering life & $02(23)$ \\
FIOCN & $02(22)$
\end{tabular}

FIOCN=Fatal in the ordinary cause of nature

When admission notes for the preliminary details were analyzed, it was revealed that $97 \%(\mathrm{n}=833)$ had mentioned the age of the patient and 95\% ( $\mathrm{n}=1041)$ had mentioned the sex of the patent adequately but $52 \%(\mathrm{n}=570)$ had not mentioned the name adequately. Only 76\% ( $\mathrm{n}=833)$ out of 1102 BHTs had notes regarding the type of complaint adequately. Further, $44 \%(n=489)$ of the records had not mentioned regarding the time of the incident, while only $26 \%(\mathrm{n}=286)$ had adequate notes. Table 03 shows the analysis on admission notes 
Table 03: Analysis on admission notes

\begin{tabular}{lrrrrr}
\hline $\begin{array}{l}\text { Mentione } \\
\text { d in notes }\end{array}$ & $\begin{array}{r}\text { Name } \\
\%(\mathbf{n})\end{array}$ & $\begin{array}{r}\text { Age } \\
\%(\mathbf{n})\end{array}$ & $\begin{array}{r}\text { Sex } \\
\boldsymbol{\%}(\mathbf{n})\end{array}$ & $\begin{array}{r}\text { Compla } \\
\text { int } \\
\mathbf{\%}(\mathbf{n})\end{array}$ & $\begin{array}{r}\mathbf{N}=\mathbf{1 1 0 2} \\
\mathbf{D u r a t i o} \\
\mathbf{n} \text { since } \\
\text { incident } \\
\mathbf{\%}(\mathbf{n})\end{array}$ \\
\hline Adequate & $48(532)$ & $97(1068)$ & $95(1041)$ & $76(833)$ & $26(286)$ \\
Partially & $50(553)$ & $0.2(02)$ & $0.2(02)$ & $20(217)$ & $30(326)$ \\
NM & $01(12)$ & $02(20)$ & $05(58)$ & $04(51)$ & $44(489)$ \\
NA & $0.5(05)$ & $01(12)$ & $0.1(01)$ & $0.1(01)$ & $0.1(01)$
\end{tabular}

$\mathrm{NM}=$ Not mentioned, NA=Not applicable

Examination findings on admission were analyzed and the conscious level was adequately observed in $65 \%(\mathrm{n}=719)$ of the records while $19 \%(\mathrm{n}=211)$ had not mentioned regarding conscious level. Of them, $86 \%(\mathrm{n}=950)$ had recorded the pulse rate on admission while blood pressure was recorded in $90 \%$ $(n=994)$. Smell of alcohol or any evidence of being under the influence of alcohol was mentioned in 39\% $(n=432)$ of the records. Table 04 shows the distribution of examination findings on admission.

Table 4: Examination findings on admission

\begin{tabular}{lrrrrr}
\hline $\begin{array}{l}\text { Mentione } \\
\text { d in notes }\end{array}$ & $\begin{array}{r}\text { LOC } \\
\%(\mathbf{n})\end{array}$ & $\begin{array}{r}\text { Pulse } \\
\%(\mathbf{n})\end{array}$ & $\begin{array}{r}\text { BP } \\
\%(\mathbf{n})\end{array}$ & $\begin{array}{r}\text { Alcohol } \\
\%(\mathbf{n})\end{array}$ & $\begin{array}{r}\mathbf{N = 1 1 0 2} \\
\mathbf{D r u g s} \\
\%(\mathbf{n})\end{array}$ \\
\hline Adequate & $65(719)$ & $86(950)$ & $90(994)$ & $39(432)$ & $02(24)$ \\
Partially & $16(172)$ & $01(06)$ & $01(06)$ & $0.1(01)$ & $00(00)$ \\
NM & $19(211)$ & $13(146)$ & $09(102)$ & $60(663)$ & $97(1073)$ \\
NA & $00(00)$ & $00(00)$ & $00(00)$ & $01(06)$ & $01(05)$
\end{tabular}

$\mathrm{NM}=$ Not mentioned, NA=Not applicable, LOC=Level of consciousness $\quad \mathrm{BP}=$ Blood pressure

There were $85 \%(n=932)$ of the records with adequate mentioning of management instructions on admission. Table 05 shows the management instruction details on admission.

Table 05: Management instruction on admission

\begin{tabular}{lr}
\hline Mentioned in notes & $\mathbf{N}=\mathbf{1 1 0 2}$ \\
$\mathbf{\%}(\mathbf{n})$
\end{tabular}

Nature of the injuries were described adequately in $65 \%(n=720)$ of the records while locations of the injuries were observed only in $29 \%(n=316)$. Table 06 shows the documentation of injuries.
Table 06: Documentation of injuries

\begin{tabular}{lrr}
\hline Mentioned in notes & $\begin{array}{r}\text { Nature } \\
\text { \% (n) }\end{array}$ & $\begin{array}{r}\mathbf{N = 1 1 0 2} \\
\text { Location } \\
\mathbf{\%}(\mathbf{n})\end{array}$ \\
\hline Adequate & $65(720)$ & $29(316)$ \\
Partially & $26(282)$ & $59(652)$ \\
Not mentioned & $08(94)$ & $11(120)$ \\
Not applicable & $01(06)$ & $01(14)$
\end{tabular}

There were records regarding ordered investigations in $87 \%(\mathrm{n}=958)$. The results of the investigations were observed to be recorded in $67 \%(n=743)$. Table 07 shows the records on investigations.

Table 07: Records on investigations

\begin{tabular}{lrr}
\hline Mentioned in notes & $\begin{array}{r}\text { Request } \\
\%(\mathrm{n})\end{array}$ & $\begin{array}{r}\mathrm{N}=1102 \\
\text { Results } \\
\%(\mathrm{n})\end{array}$ \\
\hline Adequate & $87(958)$ & $67(743)$ \\
Partially & $07(72)$ & $18(193)$ \\
Not mentioned & $03(34)$ & $11(123)$ \\
Not applicable & $03(38)$ & $04(43)$
\end{tabular}

Notes regarding surgical procedure was adequately observed only in $39 \%(n=425)$. However, there were $40 \% \quad(n=436)$ patients who had not undergone surgery. Out of the $60 \%(\mathrm{n}=666)$ patients who had undergone surgery, only 64\% $(\mathrm{n}=425)$ had got adequate notes. Table 08 shows the notes regarding surgeries.

Table 08: Notes regarding surgery

\begin{tabular}{lr}
\hline Mentioned in notes & $\begin{array}{r}\mathbf{N}=\mathbf{1 1 0 2} \\
\mathbf{\%}(\mathbf{n})\end{array}$ \\
\hline Adequate & $39(425)$ \\
Partially & $15(168)$ \\
Not mentioned & $06(73)$ \\
Not applicable & $40(436)$ \\
\hline
\end{tabular}

Out of the 593 records with complete or partially mentioned surgical procedures 39\% $(n=229)$ had described what the procedure was carried out. Only $61 \%(n=362)$ had records regarding internal findings. Significant negatives were recorded only on $16 \%(\mathrm{n}=95)$. Date of the surgery was recorded in $48 \%(\mathrm{n}=287)$. Name of the surgeon was observed only in $48 \%(\mathrm{n}=285)$ records. Table 09 shows the details of surgical notes. 
Table 09: Details of Surgical notes

\begin{tabular}{lr}
\hline Findings recorded in surgical & $\begin{array}{r}\mathbf{N}=\mathbf{5 9 3} \\
\mathbf{\%}(\mathbf{n})\end{array}$ \\
\hline notes & $39(229)$ \\
Type of surgical procedure & $61(362)$ \\
Significant findings (positive) & $16(95)$ \\
Date of surgery & $48(287)$ \\
Name of the surgeon & $48(285)$ \\
\hline
\end{tabular}

Even though making note regarding level of consciousness on admission was high, when the category of hurt was FIOCN (21 out of 22) endangering life (19 out of 23) the medical officers have failed to mention about it in 5 patients even with these serious categories. Similar findings were observed regarding other vital signs (Pulse and blood pressure) as well as for management details. Table 10 shows the comparison between admission notes and category of hurt.

Table 10: Comparison between admission notes and the category of hurt

\begin{tabular}{|c|c|c|c|c|c|c|}
\hline $\begin{array}{l}\text { Details } \\
\text { recorde } \\
\text { d on } \\
\text { admissi } \\
\text { on }\end{array}$ & $\begin{array}{l}\text { Mentione } \\
d \text { in notes }\end{array}$ & $\begin{array}{r}\text { NG } \\
N=704 \\
\%(n)\end{array}$ & $\begin{array}{r}\text { GH } \\
\mathbf{N}=353 \\
\%(\mathbf{n})\end{array}$ & $\begin{array}{r}\text { EL } \\
\mathbf{N}=23 \\
\% \text { (n) }\end{array}$ & $\begin{array}{r}\text { FIOCN } \\
\mathbf{N}=\mathbf{2 2} \\
\% \text { (n) }\end{array}$ & $\begin{array}{r}\mathbf{N}=1102 \\
\text { Total } \\
\% \text { (n) }\end{array}$ \\
\hline LOC & $\begin{array}{l}\text { Adequate } \\
\text { Partially } \\
\text { NM }\end{array}$ & $\begin{array}{l}62(435) \\
16(117) \\
22(152)\end{array}$ & $\begin{array}{r}69(244) \\
15(54) \\
15(55)\end{array}$ & $\begin{array}{l}83(19) \\
04(01) \\
13(03)\end{array}$ & $\begin{array}{l}95(21) \\
00(00) \\
05(01)\end{array}$ & $\begin{array}{l}65(719) \\
16(172) \\
19(211)\end{array}$ \\
\hline PR & $\begin{array}{l}\text { Adequate } \\
\text { Partially } \\
\text { NM }\end{array}$ & $\begin{array}{r}84(594) \\
0.4(03) \\
15(107)\end{array}$ & $\begin{array}{r}89(315) \\
0.2(01) \\
10(37)\end{array}$ & $\begin{array}{l}91(21) \\
09(02) \\
00(00)\end{array}$ & $\begin{array}{l}91(20) \\
00(00) \\
09(02)\end{array}$ & $\begin{array}{r}86(950) \\
01(06) \\
13(146)\end{array}$ \\
\hline BP & $\begin{array}{l}\text { Adequate } \\
\text { Partially } \\
\text { NM }\end{array}$ & $\begin{array}{r}90(630) \\
0.2(02) \\
10(72)\end{array}$ & $\begin{array}{r}91(323) \\
0.5(02) \\
08(28)\end{array}$ & $\begin{array}{l}87(20) \\
09(02) \\
04(01)\end{array}$ & $\begin{array}{l}95(21) \\
00(00) \\
05(01)\end{array}$ & $\begin{array}{r}90(994) \\
01(06) \\
09(102)\end{array}$ \\
\hline Manag & $\begin{array}{l}\text { Adequate } \\
\text { Partially } \\
\text { NM }\end{array}$ & $\begin{array}{r}84(590) \\
14(95) \\
02(19)\end{array}$ & $\begin{array}{r}86(303) \\
12(42) \\
02(08)\end{array}$ & $\begin{array}{l}78(18) \\
22(05) \\
00(00)\end{array}$ & $\begin{array}{l}95(21) \\
05(01) \\
00(00)\end{array}$ & $\begin{array}{r}85(932) \\
13(143) \\
02(27)\end{array}$ \\
\hline
\end{tabular}

Manag=Management, NM=Not mentioned, LOC=Loss of consciousness, $\mathrm{PR}=$ Pulse rate, $\mathrm{BP}=\mathrm{Blood}$ pressure, $\mathrm{NG}=\mathrm{Non}$ grievous, $\mathrm{GH}=$ Grievous hurt, $\mathrm{EL}=$ Endangering life, FIOCN=Fatal in the ordinary cause of nature

Significant daily records were observed in all 22 patients with category FOCN. However, there was a significant proportion with either no records or partial records among the other categories. Table 11 shows comparison between daily notes and category of hurt.

Table 11: Daily notes Vs Category of hurt

\begin{tabular}{|c|c|c|c|c|c|}
\hline $\begin{array}{l}\text { COH } \\
\text { Mentioned } \\
\text { in notes }\end{array}$ & $\begin{array}{r}\text { NG } \\
N=704 \\
\%(n)\end{array}$ & $\begin{array}{r}\text { GH } \\
\mathbf{N}=353 \\
\%(\mathbf{n})\end{array}$ & $\begin{array}{r}\mathbf{E L} \\
\mathbf{N}=\mathbf{2 3} \\
\% \text { (n) }\end{array}$ & $\begin{array}{r}\text { FIOCN } \\
\mathbf{N}=\mathbf{2 2} \\
\%(\mathbf{n})\end{array}$ & $\begin{array}{r}\mathbf{N}=1102 \\
\text { Total } \\
\%(n)\end{array}$ \\
\hline $\begin{array}{l}\text { Adequate } \\
\text { Partially }\end{array}$ & $\begin{array}{r}88(616) \\
11(80)\end{array}$ & $\begin{array}{r}91(321) \\
07(26)\end{array}$ & $\begin{array}{l}78(18) \\
13(03)\end{array}$ & $\begin{array}{r}100(22) \\
00(00)\end{array}$ & $\begin{array}{l}89(977) \\
10(109)\end{array}$ \\
\hline $\begin{array}{l}\text { NM } \\
\text { NA }\end{array}$ & $\begin{array}{c}01(06) \\
0.2(02)\end{array}$ & $\begin{array}{r}02(05) \\
0.1(01)\end{array}$ & $\begin{array}{l}09(02) \\
00(00)\end{array}$ & $\begin{array}{l}00(00) \\
00(00)\end{array}$ & $\begin{array}{r}01(13) \\
0.2(3)\end{array}$ \\
\hline
\end{tabular}

$\mathrm{NM}=$ Not mentioned, $\mathrm{NA}=\mathrm{Not}$ applicable, $\mathrm{COH}=\mathrm{Category}$ of hurt, $\mathrm{NG}=$ Non-grievous, $\mathrm{GH}=$ Grievous hurt, $\mathrm{EL}=$ Endangering life, FIOCN=Fatal in the ordinary cause of nature

Even though the nature of injuries were recorded somewhat satisfactorily, $(86 \%(\mathrm{n}=19) \quad \mathrm{FOCN}$, $56 \%(\mathrm{n}=13)$ endangering life, $71 \%(\mathrm{n}=251)$ grievous and $62 \%(\mathrm{n}=437)$ among non-grievous), records on location of injuries were unsatisfactory $(36 \%(\mathrm{n}=8)$ of FOCN, 22\%(n=5) among endangering life, $33 \%(\mathrm{n}=115)$ out of grievous, $27 \%(\mathrm{n}=188)$ among non-grievous). Table 12 shows the comparison between records on nature and location of injuries and category of hurt.

Table 12: Records on injuries Vs category of hurt

\begin{tabular}{|c|c|c|c|c|c|c|}
\hline Injuries & $\begin{array}{r}\text { COH } \\
\text { Mentione } \\
d \text { in notes }\end{array}$ & $\begin{array}{r}\text { NG } \\
\mathrm{N}=704 \\
\%(n)\end{array}$ & $\begin{array}{r}\text { GH } \\
\mathbf{N}=\mathbf{3 5 3} \\
\% \text { (n) }\end{array}$ & $\begin{array}{r}\mathbf{E L} \\
\mathbf{N}=\mathbf{2 3} \\
\% \text { (n) }\end{array}$ & $\begin{array}{r}\text { FIOCN } \\
\mathbf{N}=\mathbf{2 2} \\
\%(\mathbf{n})\end{array}$ & $\begin{array}{r}\mathbf{N}=1102 \\
\text { Total } \\
\%(n)\end{array}$ \\
\hline \multirow[t]{4}{*}{ Nature } & Adequate & $62(437)$ & $71(251)$ & $56(13)$ & $86(19)$ & $66(720)$ \\
\hline & Partially & 27 (192) & $22(78)$ & 39 (09) & $14(03)$ & $25(282)$ \\
\hline & NM & $10(70)$ & 07 (23) & $04(01)$ & $00(00)$ & 08 (94) \\
\hline & NA & $1(05)$ & $0.2(01)$ & $00(00)$ & $00(00)$ & $01(06)$ \\
\hline \multirow[t]{4}{*}{ Location } & Adequate & $27(188)$ & $33(115)$ & $22(05)$ & $36(08)$ & $29(316)$ \\
\hline & Partially & $59(413)$ & $59(208)$ & 74 (17) & 64 (14) & $59(652)$ \\
\hline & NM & $13(92)$ & $07(27)$ & $04(01)$ & $00(00)$ & $11(120)$ \\
\hline & NA & 01 (11) & $01(03)$ & $00(00)$ & $00(00)$ & 01 (14) \\
\hline
\end{tabular}

$\mathrm{NM}=$ Not mentioned, NA=Not applicable, $\mathrm{COH}=$ Category of hurt, $\mathrm{NG}=$ Non-grievous, $\mathrm{GH}=$ Grievous hurt, $\mathrm{EL}=$ Endangering life, FIOCN=Fatal in the ordinary cause of nature

Though the requests made for investigations are recorded satisfactorily (FOCN $86 \%(\mathrm{n}=19)$, endangering life $100 \%(\mathrm{n}=23)$, grievous $93 \%(330)$ and non-grievous $83 \%(\mathrm{n}=586)$ results of the investigations were not recorded satisfactorily (FOCN 82\%( $\mathrm{n}=18)$, endangering life 65\% $(\mathrm{n}=15)$, grievous $78 \%(\mathrm{n}=277)$ and non-grievous $62 \%(n=433)$.

Table 13: Records regarding investigations Vs $\mathrm{COH}$

\begin{tabular}{|c|c|c|c|c|c|c|}
\hline $\mathbf{I x}$ & $\begin{array}{l}\text { COH } \\
\text { Mentioned } \\
\text { in notes }\end{array}$ & $\begin{array}{r}\text { NG } \\
\mathbf{N}=\mathbf{7 0 4} \\
\%(n)\end{array}$ & $\begin{array}{r}\text { GH } \\
\mathbf{N}=\mathbf{3 5 3} \\
\%(\mathbf{n})\end{array}$ & $\begin{array}{r}\text { EL } \\
\mathbf{N}=23 \\
\%(\mathbf{n})\end{array}$ & $\begin{array}{r}\text { FIOCN } \\
N=22 \\
\%(n)\end{array}$ & $\begin{array}{r}\mathbf{N}=1102 \\
\text { Total } \\
\% \text { (n) }\end{array}$ \\
\hline \multirow[t]{4}{*}{ Request } & Mentioned & $83(586)$ & $93(330)$ & $100(23)$ & $86(19)$ & $87(958)$ \\
\hline & Partially & 07 (47) & $06(22)$ & $00(00)$ & $14(03)$ & $07(72)$ \\
\hline & NM & 05 (34) & $00(00)$ & $00(00)$ & $00(00)$ & 03 (34) \\
\hline & NA & 05 (37) & $0.2(01)$ & $00(00)$ & $00(00)$ & $03(38)$ \\
\hline \multirow[t]{4}{*}{ Results } & Mentioned & $62(433)$ & 78(277) & $65(15)$ & $82(18)$ & $67(743)$ \\
\hline & Partially & 17 (123) & $16(58)$ & $35(08)$ & $18(04)$ & $18(193)$ \\
\hline & NM & $15(108)$ & 05 (15) & $00(00)$ & $00(00)$ & $11(123)$ \\
\hline & NA & 06 (40) & $01(03)$ & $00(00)$ & $00(00)$ & $04(43)$ \\
\hline
\end{tabular}

$\mathrm{Ix}=$ Investigations, NM=Not mentioned, NA=Not applicable, $\mathrm{COH}=$ Category of hurt, $\mathrm{NG}=$ Non-grievous, $\mathrm{GH}=$ Grievous hurt, $\mathrm{EL}=$ Endangering life, FIOCN=Fatal in the ordinary cause of nature

Description of the internal findings in surgical notes were satisfactory only among the ones with category FOCN $91 \%(n=20)$. It was $61 \%(n=14)$ among 
endangering life, $65 \%(\mathrm{n}=228)$ among grievous, and only $14 \%(n=100)$ among non-grievous category. Table 14 shows comparison between described surgical procedures and category of hurt.

\begin{tabular}{|c|c|c|c|c|c|}
\hline $\begin{array}{l}\quad \mathrm{COH} \\
\text { Mentioned } \\
\text { in notes }\end{array}$ & $\begin{array}{r}\text { NG } \\
\mathrm{N}=704 \\
\%(n)\end{array}$ & $\begin{array}{r}\text { GH } \\
\mathbf{N}=\mathbf{3 5 3} \\
\%(\mathbf{n})\end{array}$ & $\begin{array}{r}\mathbf{E L} \\
\mathbf{N}=\mathbf{2 3} \\
\%(\mathbf{n})\end{array}$ & $\begin{array}{r}\text { FIOC } \\
\mathbf{N} \\
\mathbf{N}=22 \\
\%(n)\end{array}$ & $\begin{array}{r}\mathbf{N}=1102 \\
\text { Total } \\
\%(n)\end{array}$ \\
\hline Described & $14(100)$ & $65(228)$ & $61(14)$ & $91(20)$ & $33(362)$ \\
\hline NM & $28(196)$ & $17(61)$ & $13(03)$ & $09(02)$ & 24 262) \\
\hline NA & $58(408)$ & $18(64)$ & $26(06)$ & $00(00)$ & $43(478)$ \\
\hline
\end{tabular}

$\mathrm{NM}=$ Not mentioned, NA=Not applicable, $\mathrm{COH}=$ Category of hurt, $\mathrm{NG}=$ Non-grievous, $\mathrm{GH}=\mathrm{Grievous}$ hurt, $\mathrm{EL}=$ Endangering life, FIOCN=Fatal in the ordinary cause of nature

\section{Discussion}

Every hospital should have a Medical Records Department or Unit as a component of good medical practice. Medical record keeping has evolved into a science of itself. A well-kept record on the bed head ticket will be the only way for the doctor to prove that the treatment was carried out with a scientific basis and timely interventions have been done. Wellkept medical records protect the interests of patients and comes to the doctor's rescue in cases of alleged medical negligence. Not only the positive findings but also pertinent negative findings need to be documented in a good clinical record. Patients are examined for medico legal purposes by Medical Officers Medico Legal or Judicial Medical Offices. The idea of medico legal examination is to assist the judiciary in solving medico legal issues. Since the medical officers medico legal are not a part of the managing team they often rely on the recorded findings on BHT s to arrive at conclusions regarding medico legal issues. A good medical record can assist the medical officers medico-legal immensely. A good record is judged by its capacity to withstand the test of time and tell the whole clinical story years after it happened. However, busy schedule of doctors keeps them away from maintaining good records. Usually they are kept very brief, incomplete, cryptic which are of no use in court matters. ${ }^{[7]}$ This makes difficulties for the clinicians practicing forensic medicine specially in addressing the most important medico legal issue they need to address, the category of hurt.

It was revealed in this study, that out of the on admission notes recording of vital signs specially regarding the level of consciousness was only $65 \%$ $(n=719)$. Level of consciousness (LOC) is an important measurement of arousability and responsiveness to stimuli from the environment by the patient. ${ }^{[8]}$ Variety of factors contribute or causes altered level of consciousness. These include alterations in the chemical environment of the brain, (e.g. exposure to poisons or intoxicants), insufficient oxygen or blood flow in the brain, and excessive pressure within the skull due to oedema or haemorrhage. This is an important factor to be considered for the category of hurt, specially if it is transient. At the time of altered consciousness or loss of conscious there is an existing threat to the life which makes the category of hurt grievous due to endangering life. Further, expert medical advice is being sought increasingly in relation to altered level of consciousness not only in criminal matters but also in civil compensation and negligence related issues. The on admission findings cannot be reconstructed. It is extremely important to have the records. Further, in-depth analysis revealed that there were few patients whose level of consciousness was not recorded even among the patents with more serious damage where category of hurt was either FOCN or endangering life. On the other hand, there were $38 \%(n=269)$ and $31 \%(n=109)$ respectively of non-grievous and grievous injury patients with no records on admission regarding level of consciousness. In the absence of records may have influenced their category of hurt. Absence of recording does not necessarily mean that the patient was conscious and rational.

On the other hand, only nearly $1 / 4$ had no adequate records regarding the nature of the complaint. After detailed history and clinical examination, the medical officer is supposed to decide whether the case need medico legal referral. The decision to label a case as medico legal case should be based on sound professional judgment, after a detailed history taking and thorough clinical examination. Failure to record the presenting complaint may lead to injustice to the patient not only in criminal justice process but also may affect his safety and due care. ${ }^{[9]}$

Further, $44 \% \quad(n=489)$ of the records had no mentioning regarding the time of the incident, while only $26 \%(n=286)$ had adequate notes. Patients often forget the chronology of events specially after facing traumatic events or the memory will be fragmented. ${ }^{[10]}$ Importance of recording time from injury to initial care, mechanism of injury, presentation etc in trauma resuscitation flowchart is highlighted considering its medico legal relevance as well as the clinical relevance in management. ${ }^{[11]}$

Nature of the injuries were described adequately only in $65 \%(n=720)$. While the locations of the injuries were recorded only in $29 \%(n=316)$. Nature of the injuries are extremely important in addressing medico legal issues including identification of the 
weapon, event reconstruction as well as for category of hurt. ${ }^{[12]}$ This also has medical significance in proper management. Similarly, location of the injuries is also extremely important. Correct recording of the location avoids confusion leading to wrong sided surgical procedure. medico legal conclusions including category of hurt, event reconstruction, possible opinion on direction, volitional activity etc. are dependent on location of injuries. ${ }^{[13]}$ Further, detailed analysis with regards to the category of hurt revealed that even among the ones with serious injuries where category of hurt was either FOCN or endangering life there were deficits in documenting nature as well as the location of injuries. At the time of medico legal examination often the injuries are surgically altered and they are bandaged. Some of these injuries cannot be visualized even for months specially the ones that are covered with Plaster of Paris support. Hence, often the forensic expert will rely on the Bed Head Ticket findings to make medico legal conclusions. On the other hand, in some cases, the forensic significance of the injuries may not become apparent until long. Thus, the initial examination and assessment findings may be the only findings available for forensic conclusions. Thus, keeping accurate records on injuries are extremely important.

In a good clinical record, it is essential to document the instructions for investigations and their findings. ${ }^{[14]}$ Even though, there were records regarding ordered investigations in $87 \%(n=958)$, the results of the investigations were observed to be recorded only in $67 \%(n=743)$. Recording the investigation results and their interpretation will give a scientific validity to the records. Forensic experts are relying on the clinician's expertise regarding the interpretation of test results. However, records on management with no scientific basis verified by investigations results will not be of any use. Further, even among the ones with very serious trauma category of hurt endangering life or above there were poor recordings regarding the results of investigations.

Royal College of Surgeons of England has prepared guidelines on operation notes but the compliance has been shown to be variable. ${ }^{[15]}$ Operative procedure, findings, date and surgeon's name are some of the principle components. In this study we noticed that even procedure carried out was not mentioned in $6 \%$ $(n=73)$ while it was partially mentioned in $15 \%$ $(\mathrm{n}=168)$. Positive internal findings were recorded in $61 \%(n=362)$ and relevant negative findings were only observed in $16 \%(n=95)$. This shows that the clinicians have not realized the significance of proper documentation of surgical findings.
Specially the forensic experts are not available at the theatre and expect to get an idea about the internal findings through surgical notes. On the other hand, when there are allegations of medical negligence due to operative complications, a properly written operative notes can protect a surgeon. [16] The category FOCN by definition is condition that is deadly if let it go in the ordinary course. Only medical interventions will save the life. However, if the interventions are not documented properly in medical records forensic experts may not be able to achieve reasonable conclusions. In our study $9 \%$ $(n=2)$ out of the FOCN category and $13 \%(n=03)$ out the endangering life category had no description of internal findings.

\section{Conclusions}

Thus, the study revealed that there are deficiencies in medical records regarding patients admitted with trauma in variety of aspects. Since the medical records are increasingly used in courts in administration of justice, maintaining the accuracy is of utmost importance. We recommend that standard operational procedures regarding medical record keeping need to be introduced. Further, the quality of records can be further improved with regular audits, continuous professional developmental activities and introducing a common format for documentation in admission, surgical procedures and investigations.

\section{References}

1. Bhullar DS, Aggarwal KK. Medico Legal Diagnosis \& Pattern of injuries with sharp weapons. J Indian Acad Forensic Med. 2007;29(4):112-4.

2. Senanayake SM. Where is the legal concept of" Injuries likely to cause death'found in Sri Lankan" Medico-legal classification of injuries". Sri Lanka Journal of Forensic Medicine, Science \& Law. 2016 Feb 6;6(2).

3. Iain Carpenter, Mala Bridgelal Ram, Giles P Croft and John G Williams Medical records and record-keeping standards. Clinical Medicine 2007; 7: 328-331

4. World Health Organization. Medical records manual: a guide for developing countries. Manila: WHO Regional Office for the Western Pacific; 2006.

5. McDermott AM, Pedersen AR, Anthony DL, Stablein T. Privacy in practice: professional discourse about information control in health care. Journal of Health Organization and Management. 2016 Apr 11.

6. Srinivasulu K, Namburi VT, Samhitha AB. Study on Documentation of Medical Records. MedicoLegal Update. 2016 Jan 1;16(1). 
7. Purnapatre S S, Sahani Bimal, Sethi Kunal; Medical records for doctors - a must, Doctor in the court. 2004; 1 : 03

8. Donaldson LJ. Doctors with problems in an NHS workforce. Bmj. 1994 May 14;308(6939):127782.

9. Reader TW, Gillespie A, Roberts J. Patient complaints in healthcare systems: a systematic review and coding taxonomy. BMJ Qual Saf. 2014 Aug 1;23(8):678-89.

10. Van der Kolk BA, Fisler R. Dissociation and the fragmentary nature of traumatic memories: Overview and exploratory study. Journal of traumatic stress. 1995 Oct 1;8(4):505-25.Dunn JA, Schroeppel TJ, Metzler M, Cribari C, Corey $\mathrm{K}$, Boyd DR. History and significance of the trauma resuscitation flow sheet. Trauma surgery $\&$ acute care open. 2018 Oct 1;3(1):e000145.

11. Barek A, Haque ST. Medicolegal Aspects of Hurt, Injury and Wound. Anwer Khan Modern
Medical College Journal. 2013 Nov 10;4(2):3741.

12.Payne-James J, Crane J, Hinchliffe JA. Injury assessment, documentation, and interpretation. In Clinical Forensic Medicine 2005 (pp. 127-158). Humana Press.

13. Mathioudakis A, Rousalova I, Gagnat AA, Saad N, Hardavella G. How to keep good clinical records. Breathe. 2016 Dec 1;12(4):369-75.

14. The Royal College of Surgeons of England (2008). Good Surgical Practice. RCS Eng Professional Standards and Regulation Available from: file:///C:/Users/Ranga/ Downloads/ GSP\%202014\%20web\%20(2).pdf

15. Thomas J. Medical records and issues in negligence. Indian journal of urology: IJU: journal of the Urological Society of India. 2009 Jul;25(3):384. 